National Marine

Fisheries Service

NOAA
Fishery Bulletin

a established in 1881 a
Spencer F. Baird

First U.S. Commissione of Fisheries and founder of Fishery Bulletin
Abstract-The daily deposition of growth increments within both sagittae and lapilli was validated for known-age laboratory-reared $\left(18^{\circ} \mathrm{C}\right)$ larval northern pike (Esox lucius) $(9-33 \mathrm{~mm}$ in standard length [SL]) sampled 1, 7, 14, 22, and 28 days after hatching. The mean otolith length at hatching was 58.1 $\mu \mathrm{m}$ (standard deviation [SD] 4.32) for sagittae (no. of larvae sampled $[n]=30)$ and $39.04 \mu \mathrm{m}$ (SD 4.04) for lapilli $(n=30)$. For both sagittae and lapilli (the otoliths of which were examined without polishing), increments were formed daily and the first increment was deposited at time of hatching. The relationship of otolith size to fish size was linear for lapilli and exponential for sagittae. The size of the sagittae increased more than that of the lapilli at about 9 days after hatching-a size increase that corresponded with an increase in larval wet weight. The age of larval northern pike was moderately difficult to determine from otoliths; the difficulty varied according to the size of the larvae. Sagittae are preferable for fish larvae of up to approximately $25 \mathrm{~mm}$ SL, but for larger individuals, lapilli are more suitable. On some of the otoliths $(79 \%$ of sagittae and $18 \%$ of lapilli), a "stress ring" was deposited that corresponded with the time of sampling from the aquaria.

Manuscript submitted 30 March 2018. Manuscript accepted 14 August 2018. Fish. Bull.: 116:302-309 (2018).

Online publication date: 5 September 2018. doi: $10.7755 /$ FB.116.3-4.8

The views and opinions expressed or implied in this article are those of the author (or authors) and do not necessarily reflect the position of the National Marine Fisheries Service, NOAA.

\title{
Daily deposition of growth increments in sagittae and lapilli of laboratory-reared larval northern pike (Esox Iucius)
}

\author{
Dariusz P. Fey (contact author)' \\ Adam M. Lejk 2,3 \\ Martyna Greszkiewicz ${ }^{1}$ \\ Email address for contact author: dfey@mir.gdynia.pl \\ 1 Department of Fisheries Oceanography and Marine Ecology \\ National Marine Fisheries Research Institute \\ ul. Kołłątaja 1 \\ 81-332 Gdynia, Poland \\ 2 Department of Logistics and Monitoring \\ National Marine Fisheries Research Institute \\ ul. Kołłątaja 1 \\ 81-332 Gdynia, Poland \\ ${ }^{3}$ Department of Fish Biology and Pisciculture \\ University of Warmia and Mazury in Olsztyn \\ ul. Oczapowskiego 5 \\ 10-719 Olsztyn, Poland
}

Identification of the survival mechanisms at early life stages of fish is exceedingly important, but it also requires the application of appropriate techniques to obtain essential information. One such technique is otolith microstructure analysis (Stevenson and Campana, 1992). This analysis provides a timeline of the life history of individuals, including the precise date of hatching, and analysis of growth rate and condition up to the observed size at capture (Campana and Jones, 1992). In fact, daily increments can be used not only for aging larvae and early juveniles, but also for fish that are several months old (Fey and Linkowski, 2006) and sometimes adults (Hüssy et al., 2010). Unfortunately, even the most precise analysis based on abundant, long-term material will be worthless if the underlying data are erroneous. The basic information that must be verified is daily increment formation and the time of first increment formation (Geffen, 1992;
Campana, 2001). Obviously, such evaluations should be performed separately for each species and otolith type (i.e., sagittae and lapilli). However, even within the same species, otolith microstructure and frequency of increment deposition can vary depending on environmental variables and larval growth rates (Campana, 1983; Folkvord et al., 2000; Fukuda et al., 2009). Moreover, preparation technique (e.g., with a sagittal view with or without polishing, or with a transverse section with one or both sides polished, etc.) should be considered because the choice of preparation technique can affect the accuracy and precision of age estimates (Fey et al., 2005). Finally, as it was recently shown by Fey (2018) for larval Baltic herring (Clupea harengus membras), even the preservation of ichthyoplankton samples in alcohol may affect otolith quality and the results of age-determination and growth-rate analysis.

Several methods can be used for 
the age validation of larval and juvenile fish (for a review, see Geffen, 1992; Campana, 2001). The most used method involves analysis of larvae of known age (e.g., Folkvord et al., 1997; Folkvord et al., 2000; Hill and Bestgen, 2014; Ding et al., 2015) and marking otoliths with alizarin or tetracycline (Secor et al., 1995; Fox et al., 2003). The marginal increment analysis method is more commonly used for adult fish, but it can be applied to larvae (Sepúlveda, 1994; Fey, 2002). Although most of such otolith microstructure analysis is performed with light microscopes, scanning electron microscopes can be used as well, especially if increment deposition occurs at low temperatures (Radtke and Fey, 1996) or during periods of starvation (Jones and Brothers, 1987; Fox et al., 2003).

The present study validates the aging method for larval northern pike (Esox lucius), a species of significant importance for both commercial and recreational fisheries and having a wide circumpolar distribution (i.e., in North America and Europe) (Craig, 2008). Although many populations of northern pike are not overexploited, in some geographical areas the species is close to extirpation, which is the case in many coastal areas of the Baltic Sea (Nilsson et al., 2014; Larsson et al., 2015; Skov and Nilsson, 2018). The reasons for population declines are over-exploitation, disappearance of suitable spawning grounds, and low recruitment (Larsson et al., 2015; Skov and Nilsson, 2018). Other factors related to human activities in coastal areas (e.g., presence of wind farms and underwater cables) should be considered, as well (Fey et al., 2019). Given their endangered status in some regions, there is a need to better understand the early life period, growth, and survival of northern pike. Therefore, it is also important to evaluate the methods applied for aging larvae and early juveniles (e.g., by enumeration of daily increments within otoliths). Unfortunately, only one publication validating age estimates of northern pike from lapilli is available (Wang and Eckmann, 1992), and no information of this kind exists on the basis of sagittae. Although Wang and Eckmann (1992) provided general information on sagittae and stated that lapilli were always much clearer to read than sagittae, no data have been presented to date on the rate of increment deposition for this otolith type.

Our goal was to estimate the periodicity of increment formation and the time of the first increment deposition on sagittae and lapilli of known-age laboratory-reared larval northern pike $(9-33 \mathrm{~mm}$ in standard length [SL]). Changes in otolith size are described in relation to larval age, SL, and weight.

\section{Material and methods}

\section{Rearing of fish larvae}

Eyed-eggs of northern pike (12 days after fertilization) from wild spawners were transported in April 2015 from the Komorowo Hatchery (northern Poland) to the laboratory of the Center of Aquaculture and Ecological Engineering, University of Warmia and Mazury in Olsztyn. For the purpose of forcing the mass hatching of larvae, the eggs were subjected to a temperature that increased within one hour by $3-4^{\circ} \mathrm{C}$. Pike larvae were kept in two separate aquaria with a water volume of $60 \mathrm{~L}$ each and initially at a density of approximately 22 indivduals/L per aquarium. Water in the aquaria was aerated and purified with a bio-filter at a constant water temperature of $18^{\circ} \mathrm{C}$ (standard deviation [SD] $0.5^{\circ} \mathrm{C}$ ). The larvae were fed ad libitum every 1.5 $\mathrm{h}$ during day light hours with Perla Larva Proactive $4.0^{1}$ commercial starter feed (Skretting, Stavanger, Norway). The aquaria were cleaned every morning, before feeding began, and dead larvae were removed. Throughout the rearing period, a natural photoperiod (14 h light/10 h dark) was applied that was characteristic of the spring photoperiod in East Central Europe.

\section{Otolith analysis}

A sample of 25 specimens was collected from each tank $7,14,22$, and 28 days after hatching (dah)]. Additionally, 15 specimens were collected on the day of hatching. The fish samples were collected between 10:00 h. and 11:00 h. The fish were preserved in 96\% alcohol. Otoliths (left and right sagittae and lapilli) were extracted from each larva and placed on microscope slides, distal surface down (sulcus up) and covered with DEPEX mounting medium (Electron Microscopy Sciences, Hatfield, PA). The otoliths without any preparation were used in the following analysis. At the time of otolith extraction, the SL of each larva was measured to the nearest $0.1 \mathrm{~mm}$, and wet weight was estimated to the nearest $0.01 \mathrm{~g}$. Length measurements were corrected for shrinkage before further analysis (Greszkiewicz and Fey, 2018). The length (i.e., maximum diameter) of all extracted otoliths ( $n=230$ pairs) was measured by using an image analysis system (Image-Pro Premier, Media Cybernetics, Inc., Rockville, MD) under an Eclipse 80i transmitted light microscope (Nikon Corp., Tokyo, Japan). The mean value of the length measurements from the left and right otoliths was used for our analysis. The total number of increments was counted by the same person on two different occasions. If the difference in estimated numbers exceeded a given number of increments ( 2 increments for 7 dah, 3 for 14 dah and 22 dah, and 4 for 28 dah ), the otolith was excluded (approximately 14-29\% of the otoliths examined). Otherwise, the mean value from the two readings was used for the analysis. Some otoliths were excluded without increment counts if there was a lack of confidence in recognizing increments. The otoliths extracted on the day of hatching of the larvae were used to confirm the position of the hatching check on otoliths of older fish.

\footnotetext{
${ }^{1}$ Mention of trade names or commercial companies is for identification purposes only and does not imply endorsement by the National Marine Fisheries Service, NOAA.
} 


\section{Data analysis}

The number of increments deposited in larval otoliths in each of the 2 aquaria (i.e., the replications) after $7,14,22$, and 28 days were compared by using $t$-tests conducted separately for each of the 4 age groups. Age validation was completed by fitting linear regression to increment number-at-age data and by analyzing the slope for the difference from 1 (analysis of covariance [ANCOVA]). Otolith sizeat-age and otolith size-at-SL data were described with best-fit functions to better visualize the patterns observed. Best-fit models for the relationship of fish growth to size (in SL) and weight at age are also presented. Statistica, vers. 12.0 (TIBCO Software, Inc., Palo Alto, CA) software was used for data analysis. Differences were considered statistically significant at $P<0.05(\alpha=0.05)$.

\section{Results}

The final number of otoliths on which increments were counted successfully was 78 for sagittae $(21 \%$ and $24 \%$ of otoliths were excluded from aquarium 1 and 2 , respectively) and 74 for lapilli (28\% and $23 \%$ of otoliths were excluded from aquarium 1 and 2 , respectively).

The mean otolith length at hatching was $58.1 \mu \mathrm{m}$ (SD 4.32) for sagittae $(n=30)$ and $39.04 \mu \mathrm{m}$ (SD 4.04) for lapilli $(n=30)$. The cores of both ototlith types were formed by a large number of primordia (Fig. 1).

The number of increments deposited in northern pike otoliths after $7,14,22$, and 28 days was not statistically different for the 2 replications ( $t$-test, $P>0.05$ for each of the 4 age groups). Therefore, the data from

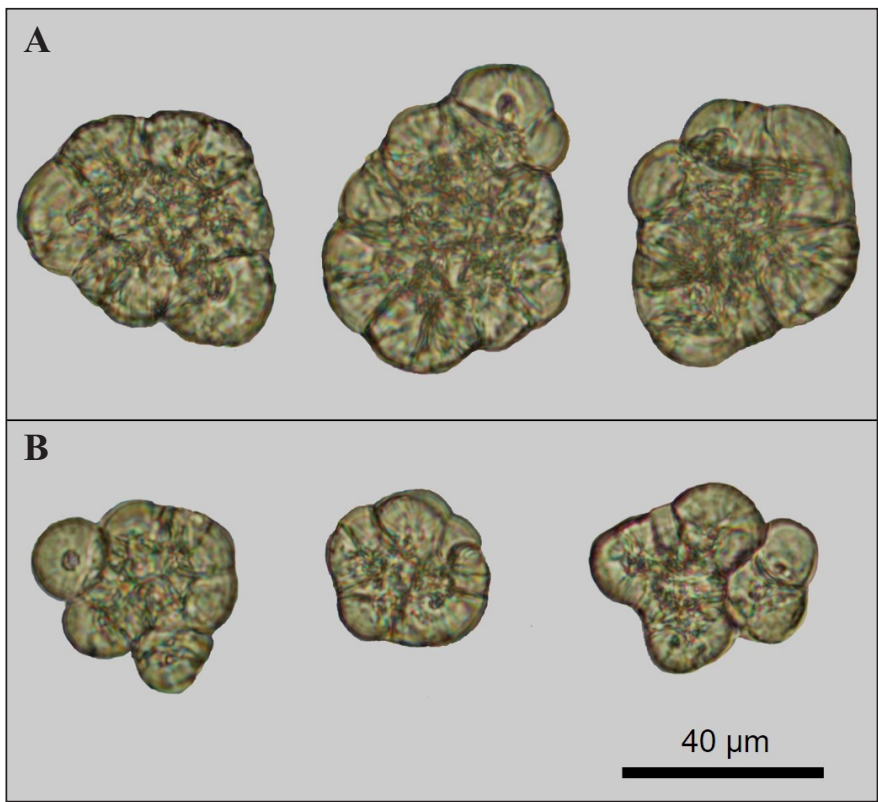

Figure 1

Images of otoliths at time of hatching of larval northern pike (Esox lucius) reared in a laboratory in 2015 at the Center of Aquaculture and Ecological Engineering, University of Warmia and Mazury in Olsztyn, Poland: (A) sagittae and (B) lapilli. Three examples are shown for each type of otolith.

the replications were pooled for further analysis. The number of increments on otoliths, both sagittae $(n=78)$ and lapilli $(n=74)$, corresponded to the known age of the larvae, as was confirmed by fitting linear regression to the increment number-at-age data (Fig. 2). The

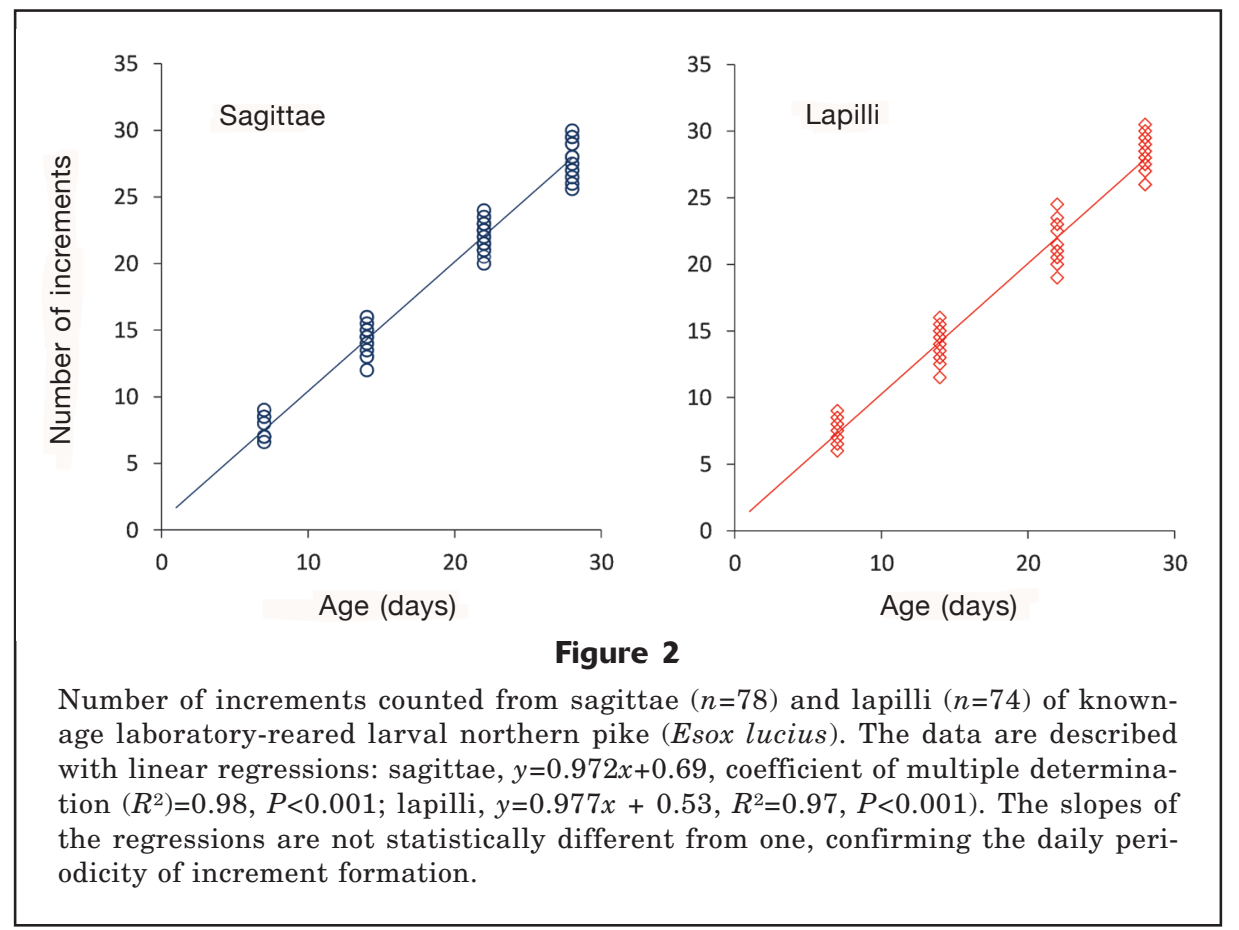




\begin{tabular}{|c|c|c|c|c|c|c|}
\hline \multicolumn{7}{|c|}{ Table 1} \\
\hline \multicolumn{7}{|c|}{$\begin{array}{l}\text { Number of increments deposited on sagittae and lapilli of known-age larval north- } \\
\text { ern pike (Esox lucius) reared in a laboratory in } 2015 \text { at the Center of Aquaculture } \\
\text { and Ecological Engineering, University of Warmia and Mazury in Olsztyn, Poland. } \\
n=\text { the number otoliths analyzed (left or right otolith was used depending on which } \\
\text { provided a clearer microstructure). }\end{array}$} \\
\hline \multirow[b]{2}{*}{$\begin{array}{l}\text { Number of days } \\
\text { after hatching }\end{array}$} & \multicolumn{3}{|c|}{ Sagittae } & \multicolumn{3}{|c|}{ Lapilli } \\
\hline & $n$ & $\begin{array}{l}\text { Mean number } \\
\text { of increments }\end{array}$ & $\mathrm{SD}$ & $n$ & $\begin{array}{l}\text { Mean number } \\
\text { of increments }\end{array}$ & $\mathrm{SD}$ \\
\hline 7 & 17 & 7.6 & 0.88 & 16 & 7.4 & 0.97 \\
\hline 14 & 21 & 14.4 & 0.65 & 18 & 13.9 & 1.47 \\
\hline 22 & 22 & 22.0 & 0.97 & 20 & 21.6 & 1.51 \\
\hline 28 & 18 & 27.8 & 1.41 & 20 & 28.1 & 1.26 \\
\hline
\end{tabular}

slopes of these two regressions were not statistically different from 1 (ANCOVA, $P>0.05$ ). The intercept of these 2 regression lines was not statistically different from 0 (ANCOVA, $P>0.05$ ), indicating that the first increment was formed at hatching (when the temperature is $18^{\circ} \mathrm{C}$ ). The mean number of increments counted in relation to real age is presented in Table 1 . The SD for lapilli was higher than that of sagittae for all age classes $(7,14$, and 22 days) except for the age of 28 days.

A stress check (i.e., a distinct dark band formed between regular increments) was formed on most $(79 \%)$ of the sagittae on the days of handling, especially on day 7, and less frequently on days 14 and 22. Stress checks were less commonly observed on lapilli (18\%). The mean number of increments between the sagittal edge and stress check formed on day 7 was 6.7 (SD 0.49, $n=14$; for 14-day-old fish), 14.8 (SD 0.67, $n=17$; for 22-day-old fish), and 21.4 (SD $0.51, n=19$; for 28-dayold fish). Therefore, the number of increments between stress check and otolith edge corresponded to the number of days elapsed after the formation of the stress check. The lower SD for the counts from the stress check to the otolith edge described above compared with the SD for the counts from the otolith center to the edge (Table 1) indicate that the source of error in increment counts is related largely to the analysis of the area close to the otolith center.

The relationship of otolith size to fish size was linear for lapilli $(n=115)$ and exponential for sagittae ( $n=115)$ (Fig. 3). The rapid change in otolith size between sagittae and lapilli, i.e., when daily increments on sagittae become significantly wider than those on lapilli, occurred around an SL of $17 \mathrm{~mm}$ and an age of 9-10 days (Fig. 3). This SL and age corresponded to the starting point of increase in fish weight (Fig. 4).

The clarity of the otolith microstructures in both sagittae (Fig. 5A) and lapilli (Fig. 5B) varied among all individuals from good, with easily distinguishable increments, to unclear and difficult to read. Generally, the lowest confidence in increment recognition was for the smallest fish ( $<17 \mathrm{~mm} \mathrm{SL}$ ), for both sagittae and lapilli. Differences between these two otolith types were evident when fish of different sizes were compared. Sagittae are preferable for northern pike larvae of up to approximately $25 \mathrm{~mm}$, but lapilli are more suitable for larger specimens.

\section{Discussion}

The number of increments on otoliths, both sagittae and lapilli, corresponded in this study to the known age of the larvae. These results can be compared with those of Wang and Eckmann (1992) who also confirmed the daily deposition of increments on the lapilli of larval northern pike. No published data on increment formation exist for sagittae that could be used for comparison with data from the present results. The results obtained in the current study at a relatively high temperature of $18^{\circ} \mathrm{C}$ should be supplemented in the future with data obtained at lower temperatures that could potentially cause non-daily increment formation or the formation of increments that are too narrow to be identified with a transmitted light microscope. Wang and Eckmann (1992) analyzed increment development in lapilli at $16^{\circ} \mathrm{C}$ and $10^{\circ} \mathrm{C}$, but it would still be valuable to analyze samples at temperatures below $10^{\circ} \mathrm{C}$. Such temperatures that can result in age underestimation because the increments are too narrow to record have been previously reported for Atlantic herring (Clupea harengus) and turbot (Scophthalmus maximus) (Geffen, 1982) and Arctic charr (Salvelinus alpinus) (Radtke and Fey, 1996).

Depending on the species, the first increment occurs either at hatching, a day after hatching, or after the first feeding and yolk-sac absorption (Jones, 1986; Thorrold and Hare, 2002). In the present study on northern pike, conducted at a temperature of $18^{\circ} \mathrm{C}$, increment deposition started at hatching in both the 

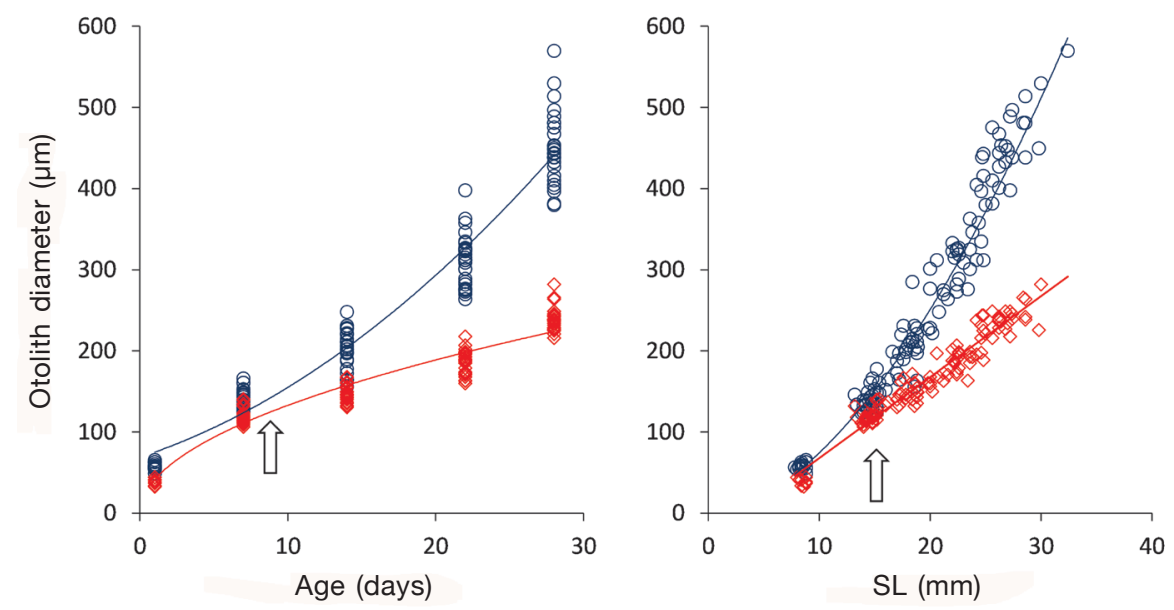

Figure 3

Changes in otolith size with age and standard length (SL) of laboratory-reared larval northern pike (Esox lucius), presented separately for sagittae ( $n=125$, circles) and lapilli ( $n=125$, diamonds). The data are described by best-fit regressions. Age from sagittae: $y=0.264 x^{2}+6.234 x+60.14$, coefficient of multiple determination $\left(R^{2}\right)=0.97, P<0.001$. Age from lapilli: $y=39.457 x^{0.52}, R^{2}=0.97, P<0.001$. Standard length from sagittae: $y=1.307 x^{1.76}, R^{2}=0.97, P<0.001$. Standard length from lapilli: $y=9.983 x-31.96, R^{2}=0.95, P<0.001$. Arrows indicate approximate age and SL at which the growth of sagittae accelerated in contrast with that of lapilli.

sagittae and the lapilli, as has been reported before for many species (Isely and Noble, 1987; Bestgen and Bundy, 1998). Different results were obtained for northern pike by Wang and Eckmann (1992), who reported that increment formation in lapilli started 2-3 dah. Such a difference in first increment formation among different studies has been reported for other species. For example, increment formation starts at hatching in larval smallmouth bass (Micropterus dolomieu) in constantly fluctuating diel water temperatures (Hill and Bestgen, 2014). This finding contradicted the results of a previous study for the same species by Graham and Orth (1987), who reported that increment formation starts 7-11 dah. Similarly, Fey et al. (2005) reported that the first increment appeared at hatching in larval spot (Leiostomus xanthurus), whereas Peters et al. ${ }^{2}$ identified it at five dah at first feeding. The reasons for such discrepancies could be related to the otolith preparation method or the lack of such preparation. The present study is based on unprepared otoliths, but the paper by Wang and Eckmann (1992) is based on increment counts from otoliths that were ground and polished. Although otolith preparation by grinding and polishing can reveal increments and facilitate correct

\footnotetext{
2 Peters, D. S., J. C. DeVane Jr., M. T. Boyd, L. C. Clements, and A. B. Powell. 1978. Preliminary observations on feeding, growth, and energy budget of larval spot (Leiostomus xanthurus). In Ann. Rep. Southeast Fish. Cent., Beaufort Lab. to U.S. Dep. Energy, p. 377-397. Beaufort Lab., Natl. Mar. Fish. Serv., NOAA, Beaufort, NC.
}

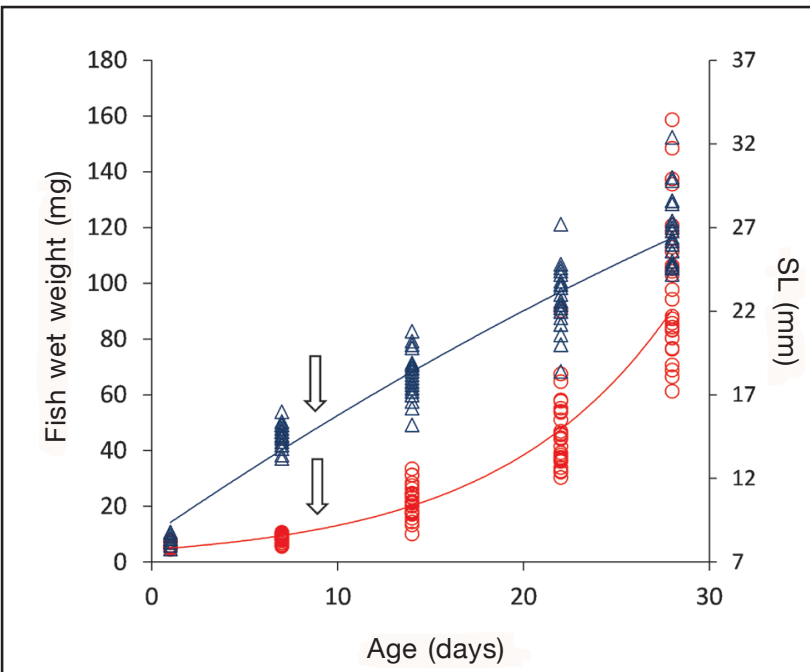

Figure 4

Growth of laboratory-reared larval northern pike (Esox lucius) in standard length (SL, $n=125$, triangles) and wet weight ( $n=125$, circles) during the first 28 days of life. The data are described by best-fit regressions: SL, $y=-0.0045 x^{2}+0.717 x+8.61$, coefficient of multiple determination $\left(R^{2}\right)=0.93, P<0.001$; wet weight: $y=4.503 \mathrm{e}^{0.107 x}$, $R^{2}=0.94, P<0.001$. Arrows indicate the age when growth in wet weight (bottom arrow) and SL (top arrow) of sagittae accelerated in contrast with that of lapilli. 


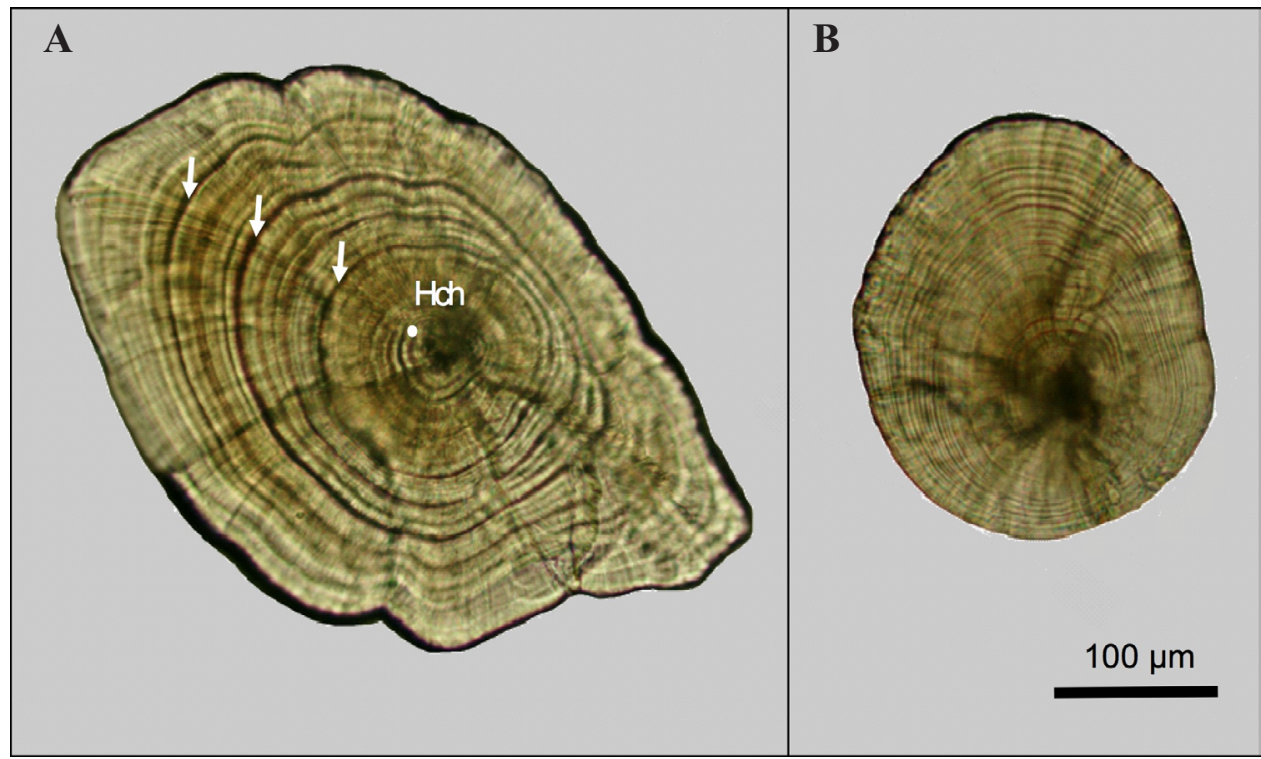

Figure 5

Images of otolith microstructure of a laboratory-reared larval northern pike (Esox lucius) 28 days after hatching: (A) sagitta and (B) lapillus. The white dot indicates the hatching check (Hch) and arrows indicate stress checks that correspond with days of handling (i.e., sampling of larvae from aquaria).

age estimates, it can also remove increments and lead to the underestimation of ages. The narrowest increments at the otolith center, in particular, can be affected during preparation (Secor et al. ${ }^{3}$; Fey et al., 2005). The most important source of inaccuracy is interpretation error among investigators (Campana, 1990). Interpretation depends on the experience of the reader and clarity of the otoliths, the latter of which may be affected by increment width. The increment width in turn is not only species specific, but it can also be affected by factors such as temperature, feeding conditions, and somatic growth (Campana, 1983; Folkvord et al., 2000; Fukuda et al., 2009). Although Wang and Eckmann (1992) reported that increment deposition started 2-3 dah, they referred to fish held in waters at a temperature of $10^{\circ} \mathrm{C}$. For fish held at a temperature of $16^{\circ} \mathrm{C}$, the delay in first increment formation described by Wang and Eckmann (1992) was only 1-2 days. It is possible that the clarity of the microstructure in the otoliths from the present study conducted with fish held at a temperature of $18^{\circ} \mathrm{C}$ was greater and therefore first increment formation was found to occur at hatching. Thus, it can be suggested that increment formation starts at hatching but, depending on the temperature at hatching, some age underestimation may occur because of problems with recognition of increments that are very narrow. Considering the

\footnotetext{
${ }^{3}$ Secor, D. H., J. M. Dean, and E. H. Laban. 1991. Manual for otolith removal and preparation for microstructural examination, 85 p. Electric Power Res. Inst., Palo Alto, CA, and Belle W. Baruch Inst. Mar. Biol. Coast. Res., Clemson, SC.
}

above conditions, the importance of repeated evaluations of the timing of increment deposition and first increment formation is emphasized.

The relationship of otolith size to fish size was linear for lapilli and exponential for sagittae. Rapid differentiation in otolith size between sagittae and lapilli, i.e., when daily increments in sagittae become significantly wider than those in lapilli, occurred when fish growth in weight increased. Therefore, if larvae larger than 17 $\mathrm{mm}$ SL are used for age estimates, wider increments in sagittal otoliths would be more suitable for measurements of increment width otolith back-calculations of growth. Fey et al. (2005) made the opposite recommendation (i.e., lapilli are better for back-calculations of growth) for larval spot. Although sagittae had wider increments than lapilli, their irregular pattern made width measurements along one radius impossible.

When aging itself was concerned, in the present study sagittae provided slightly better visibility and clarity of increments than lapilli in fish of up to $25 \mathrm{~mm}$ SL. In larger specimens (25-33 $\mathrm{mm}$ SL), the usefulness of sagittae decreased, and that of lapilli increased slightly. In sagittae, difficulties resulted particularly from wide and relatively irregular increment formation with the result that many subdaily structures that can sometimes be difficult to distinguish from "real" increments. In lapilli, when optimal focus of the microscope is used, increment patterns are seen as more regular and are seen as daily increments, but when the focus is changed from that optimum, the daily increments have a tendency to merge and result in an underestimation of real age. Notice, however, that the quality of otolith microstructures in laboratory-reared fish 
is frequently worse than in fish occurring in the wild. For example Graham and Orth (1987) reported that the clarity of otolith increments in laboratory-reared smallmouth bass was less than that viewed in wild individuals. It could also have been the case that in the present study, the clarity of otoliths of northern pike larvae was not as good as it possibly could have been if the otoliths were collected from wild fish. As with the present results, lapilli are found to be useful for aging in many species (e.g., Hoff et al., 1997; Bestgen and Bundy, 1998). Ichimaru and Katsunori (1995) preferred lapilli for collecting age data for two species of flyingfish larvae (Cheilopogon doederleini and Cypselurus hiraii) because the increments in the lapilli were as clear as those in the sagittae and did not require any preparation. Bestgen and Bundy (1998) reported that increments deposited on the sagittae of Colorado pikeminnow (Ptychocheilus lucius) were difficult to distinguish after the fish were 30 days old. Therefore, those authors used lapilli to age older fish.

On some of the otoliths (mostly sagittae) a stress check was deposited on day 7 (and less frequently on days 14 and 22), which corresponded with the time of sample collection from the aquaria. Increment counts between the otolith edge and the check formed on day 7 provided additional confirmation of daily periodicity of increment deposition. Stress checks related to handling are frequently observed on larval fish otoliths, and some authors use them, as we did in this study, as markers for increment validation (Volk et al., 1984; Boehlert and Yoklavich, 1985). Moreover, lower SD for the counts from the stress check to the otolith edge, compared with SD for counts from the otolith center to the edge, suggests that the source of error in aging northern pike is related largely to distinguishing increments in the central otolith area (approximately first 7 days). A more irregular increment pattern in the otolith center was also reported in northern pike by Wang and Eckmann (1992).

\section{Acknowledgments}

This article is a contribution to statutory project Dot18/PIKE conducted at the National Fisheries Research Institute and financed by the Ministry of Science and Higher Education, Poland. Part of this work was co-financed by statutory project no. 18.610.001-300 conducted at the Department of Fish Biology and Pisciculture, University of Warmia and Mazury in Olsztyn. The authors would like to thank M. Teodorowicz from Komorowo Fish Farm for technical support during incubation of fish eggs and H. Wróblewska for help with otolith extraction.

\section{Literature cited}

Bestgen, K. R., and J. M. Bundy.

1998. Environmental factors affect daily increment de- position and otolith growth in young Colorado squawfish. Trans. Am. Fish. Soc. 127:105-117. Article

Boehlert, G. W., and M. M. Yoklavich.

1985. Larval and juvenile growth of sablefish, Anoplopoma fimbria, as determined from otolith increments. Fish. Bull. 83:475-481.

Campana, S. E.

1983. Feeding periodicity and the production of daily growth increments in otoliths of steelhead trout ( $\mathrm{Sal}$ mo gairdneri) and starry flounder (Platichthys stellatus). Can. J. Zool. 61:1591-1597. Article

1990. How reliable are growth back-calculations based on otoliths? Can. J. Fish. Aquat. Sci. 47:2219-2227. Article

2001. Accuracy, precision, and quality control in age determination, including a review of the use and abuse of age validation methods. J. Fish Biol. 59:197-242. Article

Campana, S. E., and C. M. Jones.

1992. Analysis of otolith microstructure data. In Otolith microstructure examination and analysis (D. K. Stevenson and S. E. Campana, eds.), p. 73-100. Can. Spec. Publ. Fish. Aquat. Sci. 117.

Craig, J. F.

2008. A short review of pike ecology. Hydrobiologia 601:5-16. Article

Ding, C., Y. Chen, D. He, and J. Tao.

2015. Validation of daily increment formation in otoliths for Gymnocypris selincuoensis in the Tibetan Plateau, China. Ecol. Evol. 5:3243-3249. Article

Fey, D. P.

2002. Formation of daily increments in otoliths of larval and juvenile herring (Clupea harengus L.) and early juvenile smelt (Osmerus eperlanus L.) in low-food conditions. Arch. Fish. Mar. Res. 49:189-197.

2018. The effect of preserving ichthyoplankton samples in alcohol on the accuracy of data obtained from otolith microstructure examinations. Fish. Res. 206:198-201. Article

Fey, D. P., and T. B. Linkowski.

2006. Predicting juvenile Baltic cod (Gadus morhua) age from body and otolith size measurements. ICES J. Mar. Sci. 63:1045-1052. Article

Fey, D. P., G. E. Bath Martin, J. A. Morris, and J. A. Hare.

2005. Effect of type of otolith and preparation technique on age estimation of larval and juvenile spot (Leiostomus xanthurus). Fish. Bull. 103:544-552.

Fey, D. P., M. Greszkiewicz, Z. Otremba, and E. Andrulewicz. 2019. Effect of static magnetic field on the hatching success, growth, mortality, and yolk-sac absorption of larval northern pike Esox lucius. Sci. Total Environ. 647:1239 1244. Article

Folkvord, A., K. Rukan, A. Johannessen, and E. Moksness. 1997. Early life history of herring larvae in contrasting feeding environments determined by otolith microstructure analysis. J. Fish Biol. 51(suppl. A):250-263. Article

Folkvord, A., G. Blom, A. Johannessen, and E. Moksness. 2000.v Growth-dependent age estimation in herring (Clupea harengus L.) larvae. Fish. Res. 46:91-103. Article

Fox, C. J., A. Folkvord, A. J. Geffen.

2003. Otolith micro-increment formation in herring $\mathrm{Clu}$ pea harengus larvae in relation to growth rate. Mar. Ecol. Prog. Ser. 264:83-94. Article

Fukuda, N., M. Kuroki, A. Shinoda, Y. Yamada, A. Okamura, J. Aoyama, and K. Tsukamoto.

2009. Influence of water temperature and feeding regime 
on otolith growth in Anguilla japonica glass eels and elvers: does otolith growth cease at low temperatures? J. Fish Biol. 74:1915-1933. Article

Geffen, A. J.

1982. Otolith ring deposition in relation to growth rate in herring (Clupea harengus) and turbot (Scophthalmus maximus) larvae. Mar. Biol. 71:317-326. Article

1992. Validation of otolith increment deposition rate. In Otolith microstructure examination and analysis (D. K. Stevenson and S. E. Campana, eds.), p. 101-113. Can. Spec. Publ. Fish. Aquat. Sci. 117.

Graham, R. J., and D. J. Orth.

1987. Otolith aging of young-of-the-year smallmouth bass. In Age and growth of fish (R. C. Summerfelt and G. E. Hall, eds.), p. 486-491. Iowa State Univ. Press, Ames, IA.

Greszkiewicz, M., and D. P. Fey.

2018. Effect of preservation in formalin and alcohol on the growth rate estimates of larval northern pike. North Am. J. Fish. Manage. 38:601-605. Article

Hill, A. A., and K. R. Bestgen.

2014. Otolith daily increment deposition in age-0 smallmouth bass reared in constant and fluctuating water temperatures. North Am. J. Fish. Manage. 34:774-779. Article

Hoff, G. R., D. J. Logan, and D. F. Markle.

1997. Notes: otolith morphology and increment validation in young Lost River and shortnose suckers. Trans. Am. Fish. Soc. 126:488-494. Article

Hüssy, K., H.-H. Hinrichsen, D. P. Fey, Y. Walther, and A. Velasco.

2010. The use of otolith microstructure to estimate age in adult Atlantic cod (Gadus morhua). J. Fish Biol. 76:1640-1654. Article

Ichimaru, T., and T. Katsunori.

1995. Otolith increment formation of flyingfishes larvae, Cypselurus heterurus doederleini and Cypselurus hiraii under rearing conditions. Bull. Nagasaki Prefect. Inst. Fish. 21:1-6.

Isely, J. J., and R. L. Noble.

1987. Validation of daily ring deposition in otoliths of wild young-of-the-year largemouth bass. Tex. J. Sci. 39:273-277.

Jones, C.

1986. Determining age of larval fish with the otolith increment technique. Fish. Bull. 84:91-103.
Jones, C., and E. B. Brothers.

1987. Validation of otolith increment aging technique for striped bass, Morone saxatilis, larvae reared under suboptimal feeding conditions. Fish. Bull. 85:171-178.

Larsson, P., P. Tibblin, P. Koch-Schmidt, O. Engstedt, J. Nilsson, O. Nordahl, and A. Forsman.

2015. Ecology, evolution, and management strategies of northern pike populations in the Baltic Sea. Ambio 44(suppl. 3):451-61. Article

Nilsson, J., O. Engstedt, and P. Larsson.

2014. Wetlands for northern pike (Esox lucius L.) recruitment in the Baltic Sea. Hydrobiologia 721:145-154. Article

Radtke, R., and D. P. Fey.

1996. Environmental effects on primary increment formation in the otoliths of newlyhatched Arctic charr. J. Fish Biol. 48:1238-1255. Article

Secor, D. H., E. D. Houde, and D. M. Monteleone.

1995. A mark-release experiment on larval striped bass Morone saxatilis in a Chesapeake Bay tributary. ICES J. Mar. Sci. 52:87-101. Article

Sepúlveda, A.

1994. Daily growth increments in the otoliths of European smelt Osmerus eperlanus larvae. Mar. Ecol. Prog. Ser. 108:33-42.

Skov, C., and P. A. Nilsson, (eds.).

2018. Biology and ecology of pike, 402 p. CRC Press, Boca Raton, FL.

Stevenson, D. K., and S. E. Campana (eds.).

1992. Otolith microstructure examination and analysis. Can. Spec. Publ. Fish. Aquat. Sci. 117, 126 p.

Thorrold, S. R., and J. A. Hare.

2002. Otolith applications in reef fish ecology. In Coral reef fishes: dynamics and diversity in a complex ecosystem (P. F. Sale, ed.), p. 243-264. Academic Press, San Diego, CA.

Volk, E. C., R. C. Wissmar, C. A. Simenstad, and D. M. Eggers. 1984. Relationship between otolith microstructure and the growth of juvenile chum salmon (Oncorhynchus keta) under different prey rations. Can. J. Fish. Aquat. Sci. 41:126-133. Article

Wang, N., and R. Eckmann.

1992. Effects of photoperiod, feeding regime and water temperature on the formation of daily growth increments in otoliths of larval pike (Esox lucius L.). J. Appl. Ichthyol. 8:246-250. Article 